ラット高血圧腎の排泄機能：とくに水, $\mathrm{Na}$ の排泄

\begin{tabular}{|c|c|c|c|}
\hline & & & \\
\hline & & & \\
\hline 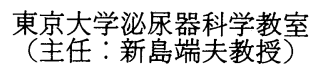 & 河 & 辺 & 香 \\
\hline & 杉 & 本 & \\
\hline & 新 & 島 & 端 \\
\hline
\end{tabular}

\title{
RENAL FUNCTION STUDIES UTILIZING KIDNEY PERFUSION IN POST-DOCA HYPERTENSIVE RATS AND SPONTANEOUSLY HYPERTENSIVE RATS (SHR) WITH SPECIAL REFERENCE TO WATER AND SODIUM EXCRETION
}

Takeo Murayama, Kazuki Kawabe, Kenzo Sugimoto and Tadao Niijima

Department of Urology, Faculty of Medicine, The University of Tokyo

Inulin clearance (Cin), water and sodium excretion were determined in experimental hypertensive rats utilizing isolated renal perfusion. To determine the effect of perfusates on water and sodium excretion, various solutions such as lactated Ringer $(\mathrm{L}), 5 \%$ glucose in water, $0.9 \%$ saline with $4 \%$ bovine serum albumin (BSA), L plus $4 \%$ BSA and $0.9 \%$ saline were used. The results obtained with $0.9 \%$ saline were almost equal or superior to those with other solutions, $0.9 \%$ saline was therefore used for the following experiments.

In spontaneously hypertensive rats (SHR), Cin, water and sodium excretion were decreased markedly at and after 5 weeks of age.

Cin in post-DOCA hypertensive rats was identical to that in Wistar rats, but Cin per kidney weight, water and sodium excretion determined by perfusion study, were significantly decreased. When renal perfusion was performed extracorporeally, the excretion was significantly larger than that from in situ kidney, indicating that denervation increased the renal excretion of water and sodium in 13-week-old SHR.

In conclusion, hypertension in SHR and post-DOCA hypertension are considered at least partly due to the impairment or renal excretion of water and sodium, and the renal nerve participates in their excretion.

要旨：腎灌流による $\mathrm{CIn}$ と水, Na 排泄を実験的高血圧ラットで検討した。まず灌流液による差をみるた めに, 生食水, ラクテック(ラクテート加リンゲル), $5 \%$ グルコース, 牛血清アルブミン加の生食水拧 よびラクテックで 5 分間灌流した結果, ラクテックと生食水にほぼ同程度の, 水, $\mathrm{Na}$ 排泄が得られたの で, 一定灌流量 $\left(1 \mathrm{ml} / \mathrm{min} / 100 \mathrm{~g}\right.$ 体重) あるいは一定灌流圧 $\left(150 \mathrm{cmH}_{2} \mathrm{O}\right.$ と $\left.200 \mathrm{cmH}_{2} \mathrm{O}\right)$ で $\mathrm{SHR}$ および post-DOCA 高血圧症ラットの腎を生食水で灌流した. SHR では，5，7，9，13週齢で検討したが， 5 週 齢よりすでに Wistar ラット腎に比して CIn は低下しており，水， Na 排泄では 7 週秢以後明らかな低下 をみた. Post-DOCA 高血圧症ラットの whole body に抢けるCInはコントロールの Wistar ラットと差 がなかったが，CPAH は低下した。一方，腎重量あたりのCInでは明らかな低下をみた。 Post-DOCA 高 血圧腎ではWistar ラット腎に比して有意な水，Na 排泄低下がみられた。一定灌流量下の実験では, in situの灌流のため腎神経のブロックは行われておらず，一方一定灌流圧実験では体外灌流のため除神経 状態下にある．両群間での13週龄 SHR に怙ける水排泄をみると除神経群で明らかな増加が見られた。

以上の結果より post-DOCA 高血圧症ラットでは腎硬化性变化による水, $\mathrm{Na}$ 排泄障害のため高血圧が 維持されており, SHR では高血圧形成あるいは維持に水, $\mathrm{Na}$ 排泄障害が関与し, 高血圧維持期に拉い 
ては腎神経が水, $\mathrm{Na}$ 排泄に関係している可能性が考えられる。

\section{緒言}

腎が高血圧の発症あるいは維持に関与しているとの 報告は多くみられ1) 4), 我々も post-DOCA 高血压症 ラットや自然発症高血圧ラット（SHR）と正常血圧 ラット間で腎移植を括こない, 腎が高血圧に深く関 わっていることを明らかにしてきだ56).腎がいかなる 機序で高血圧に関与しているかは十分な解明はなされ ていないが, ひとつの説明として Guyton 説がある7). すなわち血圧は腎に打ける水, 電解質排泄と密接な関 係にあり，腎に何らかの原因で排泄障害が生じると血 圧が上昇して pressure diuresis と natriuresis を起こ すことによって水，電解質排泄が正常に保たれる様に なる。図1はGuyton説における血圧と水, $\mathrm{Na}$ 排泄の 関係を示すものであり, Goldblatt 高血圧腎3), postsalt 高血圧腎8), Dahl 高血圧腎9)では血圧と水, $\mathrm{Na}$ 排 泄カーブの右方移動がみられ，Guyton 説を裏づける 報告がなされている.今回我々は post-DOCA 高血圧 症ラットと SHR の腎機能と腎灌流による水, $\mathrm{Na}$ 排泄 を検討し, このカーブの右方移動を示唆する結果を得 たので報告する。

\section{実験方法}

対象動物は星野実験動物飼育所より購入したWis$\operatorname{tar}$ 系ラット, 自然発症高血圧ラット (SHR), Wistar Kyotoラット（WKY）を用いた. Post-DOCA 高血圧 症ラット作成は既報5)に従い, 無麻酔下 tail cuff 法に て尾動脈圧が $150 \mathrm{mmHg}$ 以上を post-DOCA 高血圧症 ラットとし， $150 \mathrm{mmHg}$ 末満を post-DOCA 正常血圧

Fig. 1 Relationship between urinary excretion of water and sodium and arterial pressure.

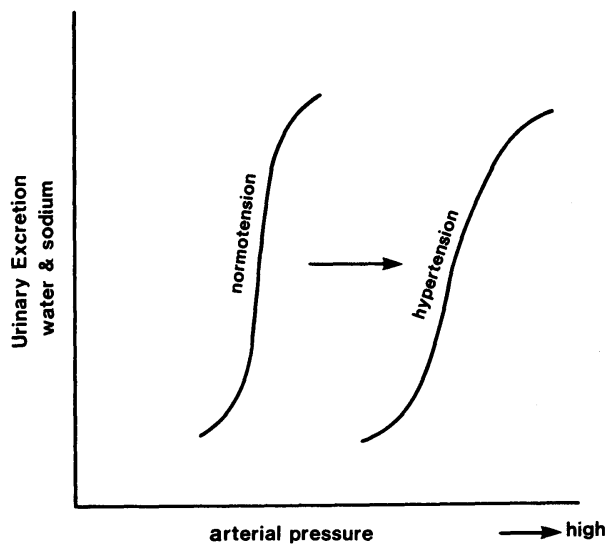

ラットとした.

イヌリン怙よび p-アミノ馬尿酸クリアランス（CIn, $\mathrm{CPAH})$ の測定 : エーテル麻醉下で左大腿部に皮切を加 完, 大腿動・静脈の各々にカテーテル（PE50）を插入 し, 動脈は採血と血圧測定に用い, 静脈はイヌリンお よび PAH の注入に用いた。膀羘へもPE50を插入し， 採尿用とし, 各々カテーテル拽入後, 皮膚縫合を行っ てからラットの上下肢を絹系にて固定して麻酔からの 覚醒を待つ. 完全覚醒後 60 分経過した後, イヌリン(1 $\mathrm{g} / 100 \mathrm{ml}$ 生食水) と $\mathrm{PAH}(400 \mathrm{mg} / 60 \mathrm{ml}$ 生食水)を 1.2 $\mathrm{ml} / \mathrm{hr}$ の速度で大腿静脈へ持続注入を開始した。注入 開始後60分にへマトクリット管で大腿動脈より採血し てから集尿を始め，30分経過後再び採血してクリアラ ンス測定を終了した(30分クリアランス法)。得られた 動脈血中のイヌリンおよび PAH 濃度を測定し，また 30 分間の尿量扣よび尿中イヌリン, PAH 濃度を測定 し, CIn と CPAHを算出した。なおイヌリンはAnthron 法, PAH は津田試薬を用いて測定した。

腎灌流法：(1) 一定灌流量下腎灌流法 (in situ) (図 2 ). ベントバルビタールの腹腔内 (ip) 麻酔下で開腹 し, 陰茎静脈より50単位へパリン（Takeda）を注入し てヘパリン化した。ついで腹部大動脈にダブルルーメ ンカテーテル (DP4)を先端が右腎動脈分岐部に位置す るように捜入し，その近位抒よび遠位部大動脈を結禁

Fig. 2 Schema of in situ renal perfusion.

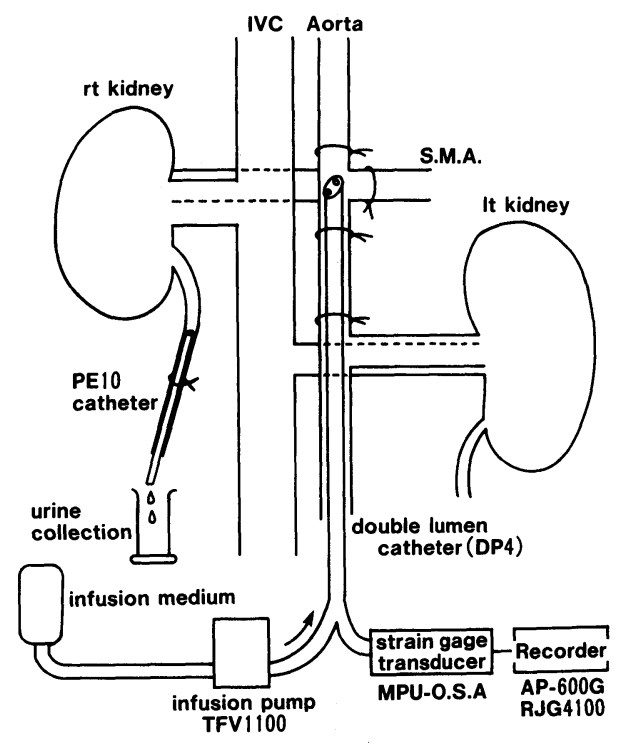


し灌流液が右腎動脈のみを流入するようにした。また 右尿管にカテーテル（PE10）を插入し，予め重量を測 定した試料ビンに接続し採尿した。腹部大動脈のダブ ルルーメンカテーテルの一方のルーメンで持続的に灌 流圧をモニターし，他方のルーメンから毎分 $1 \mathrm{ml} / 100 \mathrm{~g}$ 体重で灌流液を注入した５分間プライミングした後 5 分間灌流してその間の尿を採取した。（2）一定灌流 圧下腎灌流法 (ex vivo) (図 3).（1）と同じ操作で腹 部大動脈と尿管にカテーテルを挿入するが，大動脈へ はPE60を用いた。予め生食のボトルを $150 \mathrm{~cm}$ と200 $\mathrm{cm}$ の高さにセットしておき速やかに腎を体外に取り 出して, 腎灌流を開始する. 5 分間のフラッシングで 腎は白色を呈し，尿流出がほぼ一定となるが，これを 確認してただちに 5 分間灌流を行って採尿した。灌流 量は腎静脈からの流出量から算出したが灌流量が毎分 $1 \mathrm{ml} / 100 \mathrm{~g}$ 体重に近づくように調節した。

一定灌流量下あるいは一定灌流圧下での 5 分間灌流 にて水, $\mathrm{Na}$ 排泄を検討したが, さらに一定灌流量下で 生食 $500 \mathrm{ml}$ にイヌリン $500 \mathrm{mg}$ を溶解し 5 分間灌流に て CIn も測定した。ラットの尾動脈圧と脈拍数は夏目 製作所製 NK209を用い血中および尿中 Naは日本分 光メディカル FLAME 30c で測定した. BUN, 血清ク レアチニン（Scr）は軽いェーテル麻酔下で開腹し大動 脈血を採取し自動分析器で測定した。灌流液の浸透圧 は, DigiMatic Osmometer, また $\mathrm{pH}, \mathrm{Po}_{2}, \mathrm{Pco}_{2}$ は ILMeter 1303にて測定した。

\section{検討事項}

（1）水， $\mathrm{Na}$ 排泄に対する灌流液組成の検討

Wistar ラットを用いて一定灌流量下で 5 分間腎灌

Fig. 3 Schema of ex vivo renal perfusion.

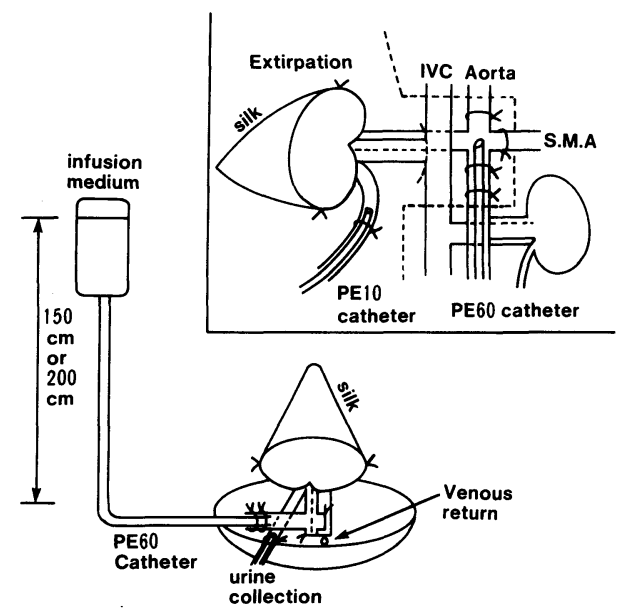

流を生食水，ラクテック (Lactated Ringer), $5 \%$ グル コース拉よび生食水とラクテックに牛血清アルブミン (4g/dl)を加光た溶液で行った。灌流直前・直後のボト ル内残液で Osm, $\mathrm{pH}, \mathrm{Po}_{2}, \mathrm{PcO}_{2}$ を測定した．灌流液組 成は各々ボトルラベル表示の值とした。

(2) Post-DOCA 正常血圧ラットと post-DOCA 高 血圧症ラットの腎機能の比較

対照として予め左腎摘を施行したWistarを用い た.

（3）SHR の週齢別の腎灌流における CIn

$5,7,9,13$ 週齢の SHR の体重, 尾動脈圧, 脈拍数 を測定した後, 5 分間腎灌流して CIn を測定したが, 対 照として同週龄の Wistarを用いた。

（4）SHR の週齢別における一定灌流量下腎灌流に よる水, $\mathrm{Na}$ 排泄

$5 ， 7 ， 9 ， 13$ 週齢 SHR 腎括よび13週齢の Wistar と WKY 腎にて施行した。

（5）一定灌流圧下腎灌流における水， $\mathrm{Na}$ 排泄

Wistar, post-DOCA 高血圧症ラット, SHRの各々 体重, 尾動脈圧, 脈拍数を測定した後, 腎灌流を行っ た.

（6）水排泄に扣ける除神経の影響

一定灌流量下腎灌流は in situ の腎であり一応神経 の支配下にある。一方，一定灌流圧下腎灌流では腎は 体外に取り出されるために完全な除神経状態にある. そこで両実験群で灌流量と灌流圧がほぼ同程度の13週 齢 Wistar および13週齢 SHR を選び各々の水排泄を 比較検討した。

\section{結 果}

（1）各種灌流液による水, $\mathrm{Na}$ 排泄の検討

生食水, ラクテック, $5 \%$ グルコース, 牛血清アル ブミン加生食水, 牛血清アルブミン加ラクテックの 各々溶液組成は表 1 の如くである。浸透圧は $5 \%$ グル コースと牛血清アルブミン加生食水で $280,282 \mathrm{mOsm} /$ $l$ と高く, ラクテックが $238 \mathrm{mOsm} / l$ と最も低值を示し た。 $\mathrm{pH}$ では牛血清アルブミンを加えた溶液が共に 5.6〜 5.7の強酸性であったが他の溶液は6.8～7.4 と弱 酸性を呈した. $\mathrm{Po}_{2}$ は牛血清アルブミン加溶液とラク テックで高值を示し, $\mathrm{Pco}_{2}$ は牛血清アルブミン加溶液 で12, 13mmHg と高値を示した。

各溶液での腎灌流による水, $\mathrm{Na}$ 排泄をみると（図 $4)$, 水排泄では生食水, ラクテック，5\%グルコース で有意差なく, 牛血清アルブミン加溶液では著しい減 少をみた. $\mathrm{Na}$ 排泄では生食水, ラクテックがほぼ同じ 
Fig. 4 Effect of perfusates on water and sodium excretion from isolated perfusated kidneys in Wistar rats.
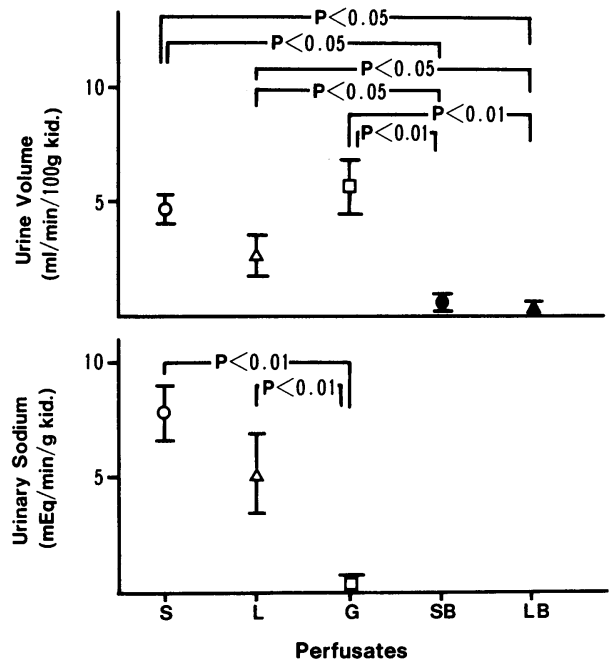

S : Saline, L: Lactec, G : $5 \%$ Glucose, SB : S+ BSA, LB : L+BSA

で，5\%グルコースは著しく減少した。なお牛血清フ ルブミン加溶液では尿量が微量のため $\mathrm{Na}$ 測定は不可 能であった。また各灌流液での灌流圧は 40 ～70 mmHg の範囲で行われ各溶液間で有意差はみられなかった。

(2) Post-DOCA 正常血圧ラットと post-DOCA 高
血圧症ラットの腎機能の比較（表 2,3 ）

Post-DOCA 正常血圧ラットの BUN はコントロー ルの Wistarに比して上昇したが, post-DOCA 高血圧 症ラットではさらに有意な高值を示した $(\mathrm{p}<0.01)$. Scr は 3 群間に有意差はみられなかった。腎重量当り のCInでは Wistarに比してむしろ post-DOCA 正常 血压ラットで有意に高值を示し $(\mathrm{p}<0.05)$, postDOCA 高血圧症ラットでは他の 2 群に比して明らか な减少をみた（ $\mathrm{p}<0.05 ）$.

Whole bodyに拉ける CInでは post-DOCA 正常血 圧ラットはWistar 怙よび post-DOCA 高血圧症ラッ トに比してむしろ低值を示したが $(\mathrm{p}<0.05, \mathrm{p}<0.01)$ ， Wistar と post-DOCA 高血圧症ラット間では有意差 はみられなかった。

CPAH は post-DOCA 正常血圧ラット, post-DOCA 高血圧症ラット共にWistarに比して有意に低值で あった $(\mathrm{p}<0.01)$.

（3） SHR の週齢別 CIn（因 5 ）

5 週齢 SHR ですでに体重は Wistarに比して低值 であり, 加齢と共に体重増加はみられるものの両群間 の差が広がる傾向を示した。

血圧は 9 週齢で 5 週齿 SHR に比して明らかな上昇 をみ，また同週齢 Wistarに比しても有意な高值と なったが，脈拍数では週齢間揖よび同週齢 Wistar と に有意差はみられなかった。

Table 1 Composition of the perfusates

\begin{tabular}{|c|c|c|c|c|c|c|c|c|c|c|c|}
\hline \multirow{2}{*}{$\begin{array}{l}\text { perfusate } \\
\text { Saline }\end{array}$} & \multirow{2}{*}{$\begin{array}{r}\mathrm{Na} \\
154\end{array}$} & \multicolumn{2}{|c|}{$\underset{\mathrm{mEq} / \mathrm{l}}{\mathrm{K}} \mathrm{Ca}$} & $\mathrm{Cl}$ & \multicolumn{2}{|c|}{$\begin{array}{l}\text { Lactose Glucose } \\
\text { W/V \% }\end{array}$} & \multirow[t]{2}{*}{$\begin{array}{l}\mathrm{BSA}^{\S} \\
\mathrm{g} / \mathrm{dl}\end{array}$} & \multirow{2}{*}{$\frac{\begin{array}{c}\text { Osm } \\
\mathrm{mOsm} / 1\end{array}}{265}$} & \multirow{2}{*}{$\begin{array}{l}\mathrm{pH} \\
6.9\end{array}$} & \multicolumn{2}{|c|}{$\underset{\mathrm{mmHg}}{\mathrm{PO}_{2}}$} \\
\hline & & & & 154 & & & & & & 158 & 8 \\
\hline Lactec & 130 & 4 & 3 & 109 & 28 & & & 238 & 6.8 & 173 & 7 \\
\hline $5 \%$ Glucose & & & & & & 5 & & 280 & 7.4 & 151 & 7 \\
\hline Saline + BSA & 154 & & & 154 & & & 4 & 282 & 5.6 & 185 & 12 \\
\hline Lactec + BSA & 130 & 4 & 3 & 109 & 28 & & 4 & 246 & 5.7 & 174 & 13 \\
\hline
\end{tabular}

$\S \mathrm{BSA}$ : Bovine Serum Albumin

Table 2 BUN, Scr and Cin in Wistar, post-DOCA nomotensive and post-DOCA hypertensive rats.

\begin{tabular}{|c|c|c|c|c|}
\hline & $\begin{array}{c}\mathrm{BP} \\
\mathrm{mmHg}\end{array}$ & $\begin{array}{l}\mathrm{BUN} \\
\mathrm{mg} / \mathrm{dl}\end{array}$ & $\begin{array}{c}\mathrm{Scr} \\
\mathrm{mg} / \mathrm{dl}\end{array}$ & $\stackrel{\text { Cin }}{\mathrm{ml} / \mathrm{min} / \mathrm{g} . \mathrm{Kid} .}$ \\
\hline Wistar $(n=5)$ & $119 \pm 1$ & $27 \pm 2$ & $0.7 \pm 0.1$ & $0.1112 \pm 0.0865$ \\
\hline $\begin{array}{l}\text { Post-DOCA } \\
\text { normotension }(n=5)\end{array}$ & $128 \pm 4$ & $34 \pm 4$ & $0.7 \pm 0.0$ & $0.1649 \pm 0.0380^{*}$ \\
\hline $\begin{array}{l}\text { Post-DOCA } \\
\text { hypertension }\end{array}(n=6)$ & $172 \pm 5^{* *}$ & $48 \pm 6^{* *}$ & $0.8 \pm 0.1$ & $0.0632 \pm 0.0049^{* \dagger}$ \\
\hline
\end{tabular}


Table 3 Clearances of inulin and p-aminohippuric acid in Wistar, post-DOCA normotensive and post-DOCA hypertensive rats

\begin{tabular}{l|c|l|l|l|c}
\hline & \multicolumn{1}{|c|}{$\begin{array}{c}\text { BW } \\
\mathrm{g}\end{array}$} & \multicolumn{1}{c|}{$\begin{array}{c}\mathrm{BP} \\
\mathrm{mmHg}\end{array}$} & HR & \multicolumn{1}{c}{$\begin{array}{c}\text { Cin } \\
\mathrm{ml} / \mathrm{min}\end{array}$} & $\begin{array}{c}\mathrm{C}_{\mathrm{PAH}} \\
\mathrm{ml} / \mathrm{min}\end{array}$ \\
\hline $\begin{array}{l}\text { Wistar }(\mathrm{n}=4) \\
\begin{array}{l}\text { Post-DOCA } \\
\text { normotension }\end{array}\end{array}$ & $278 \pm 8$ & $115 \pm 11$ & $418 \pm 11$ & $1.260 \pm 0.300$ & $3.059 \pm 0.475$ \\
$\begin{array}{l}\text { Post-DOCA } \\
\text { hypertension }\end{array}$ & $463 \pm 24^{* *}$ & $128 \pm 8$ & $398 \pm 16$ & $0.797 \pm 0.154^{*}$ & $1.800 \pm 0.594^{* *}$ \\
\hline & $448 \pm 31^{* *}$ & $168 \pm 5^{* *+\dagger}$ & $430 \pm 31$ & $1.719 \pm 0.365^{\dagger \dagger}$ & $1.735 \pm 0.255^{* *}$ \\
\hline
\end{tabular}

Fig. 5 Body weight, BP, heart rate and Cin at each age of Wistar rats and SHR.
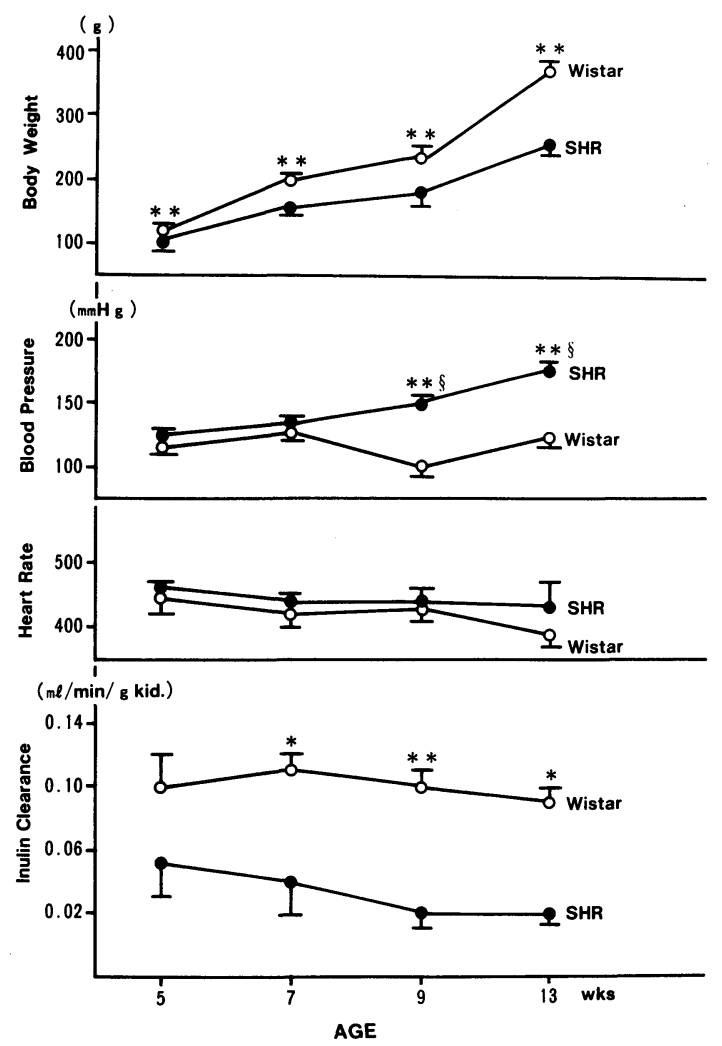

${ }^{*} \mathrm{p}<0.05,{ }^{* *} \mathrm{p}<0.01 ;$ vs Wistar rats. ${ }^{\S} \mathrm{p}<0.05 ;$ vs 5 wk SHR

腎灌流に拈ける CInではいずれの週龄でもSHRが Wistar に比して低值であったが有意差は 7 週齢以後 にみられた。

（4）SHR の週齢による水， Na 排泄（図 6)

体重増加は実験 3 とほぼ同様であったが，13週齢に おいてコントロールの Wistar, WKY との間で明らか な体重差はみられなかった。血圧は第 7 週柃で明らか に上昇していた。13週齢 Wistar 括よび WKY の血圧
Fig. 6 . Body weight, BP, and water and sodium excretion from isolated perfused kidney of SHR, including $13 \mathrm{wk}-\mathrm{Wistar}$ and $13 \mathrm{wk}-\mathrm{WKY}$ rats.

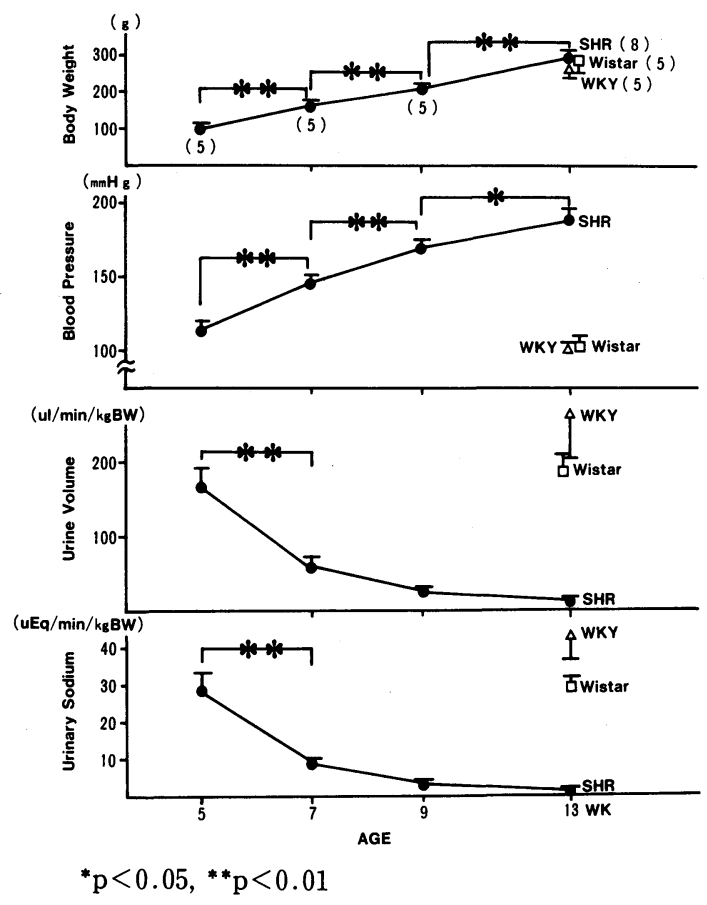

は正常域にあった。体重当たりの尿量では血圧の上昇 した 7 週齢で 5 週齢に比し明らかな減少が見られた が, この加㱓に伴ら尿量减少は, whole body でも同様 の結果であった。 Na 排泄も尿量と同様の経過をとっ た. 13週齢 Wistar, WKY 共に水, Na 排泄量に有意差 なく，また 5 週齢 SHR とほぼ同じ值であった。

（5）一定灌流圧下腎灌流に拉ける水， $\mathrm{Na}$ 排泄（表 4)

水柱圧 $150 \mathrm{~cm}, 200 \mathrm{~cm}$ 共に腎灌流量は $150 \sim 160 \mathrm{ml} /$ $\min$ とほぼ一定であった。 $150 \mathrm{cmH}_{2} \mathrm{O}$ における水排泄 は Wistar に比して post-DOCA 高血圧群, SHR 群共 に明らかな減少を示し $(p<0.01)$, この SHR の減少は 
Table 4 Urinary excretion of water and sodium under $150 \mathrm{cmH}_{2} \mathrm{O}$ and $200 \mathrm{cmH}_{2} \mathrm{O}$ perfusion pressure in Wistar, post-DOCA hypertensive and SHR kidneys

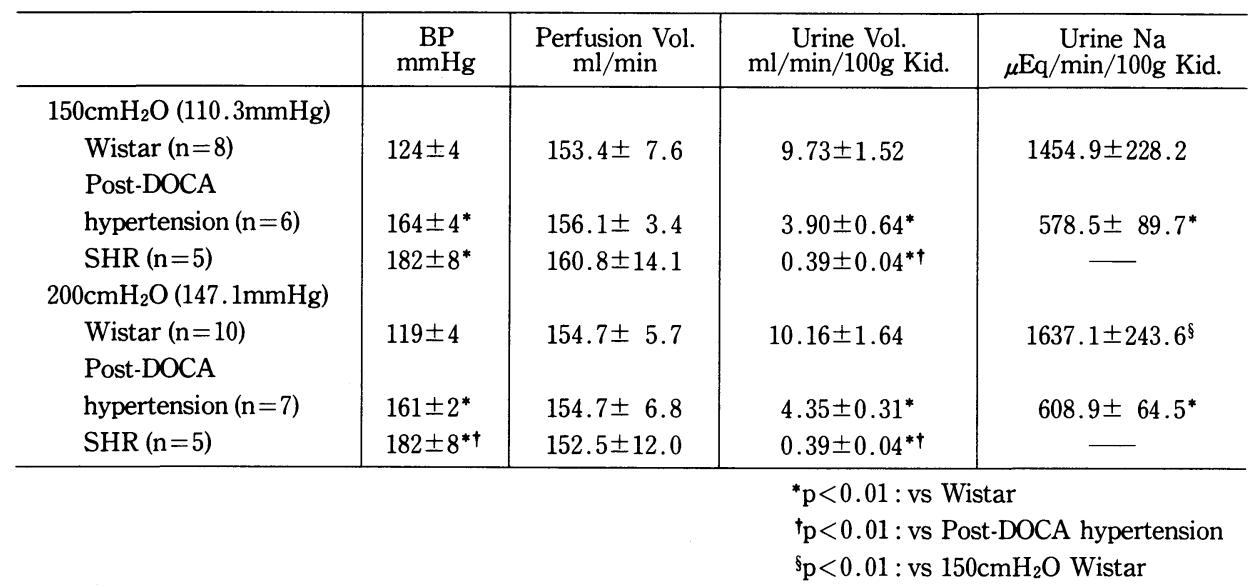

Table 5 Denervation effect on water excretion in isolated perfused kidneys of Wistar rats and SHR.

\begin{tabular}{c|c|c|c|c}
\hline & \multicolumn{2}{|c|}{ Wistar } & \multicolumn{2}{c}{ SHR (13wk) } \\
\cline { 2 - 5 } & innervated $(\mathrm{n}=6)$ & denervated $(\mathrm{n}=5)$ & innervated (n=8) & denervated (n=6) \\
\hline $\begin{array}{c}\text { Pefusion Pressure } \\
\text { (mmHg) }\end{array}$ & $114.4 \pm 9.6$ & $110.3^{\#}$ & $95.0 \pm 9.6$ & $110.3^{\#}$ \\
$\begin{array}{c}\text { Perfusion Volume } \\
(\mathrm{ml} / \mathrm{min} / 100 \mathrm{~g} \text { BW) }\end{array}$ & $1.0^{\#}$ & $1.14 \pm 0.20$ & $1.0^{\#}$ & $1.15 \pm 0.20$ \\
$\begin{array}{c}\text { Urine Volume } \\
(\mu \mathrm{l} / \mathrm{min} / \mathrm{kg} \mathrm{BW})\end{array}$ & $188.0 \pm 22.4$ & $221.8 \pm 19.6$ & $14.3 \pm 1.6$ & $24.0 \pm 2.6^{*}$ \\
\hline
\end{tabular}

${ }^{*} \mathrm{p}<0.01$ : innervated vs denervated group in SHR. \#Pre-determined values

post-DOCA 高血圧群に比して著しかった（ $\mathrm{p}<0.01)$. $\mathrm{Na}$ 排泄も Wistar に比して, post-DOCA 高血圧群で 低值を示したが，SHR では尿量が不足で，Na 測定が できなかった。

$200 \mathrm{cmH}_{2} \mathrm{O}$ でも水, $\mathrm{Na}$ 排泄は $150 \mathrm{cmH}_{2} \mathrm{O}$ と同様の 結果であった。一方 $150 \mathrm{cmH}_{2} \mathrm{O}$ と $200 \mathrm{cmH}_{2} \mathrm{O}$ では約 $36.8 \mathrm{mmHg}$ の差があるが，両灌流圧間で水， $\mathrm{Na}$ 排泄 を比較検討すると, 水排泄では Wistar, post-DOCA 高 血圧群，SHRいずれも両者間に差はみられなかった が， $\mathrm{Na}$ 排泄で Wistarにおいて $200 \mathrm{cmH}_{2} \mathrm{O}$ で有意の 増加をみた $(\mathrm{p}<0.01)$.

灌流量と水排泄量の相関を検討したが $150 \mathrm{~cm} \mathrm{H}_{2} \mathrm{O}$ で Wistar と post-DOCA 高血圧群でおのおの $\mathrm{r}=$ $0.547, \mathrm{y}=0.03 \mathrm{x}+6.39(\mathrm{p}<0.05), \mathrm{r}=0.593, \mathrm{y}=$ $0.0157 \times 10^{-3} \mathrm{x}+1.391(\mathrm{p}<0.05)$ の相関をみ，さらに 水排泄量と $\mathrm{Na}$ 排泄量でも同様で正の相関をみた。

（6）水排泄における除神経の影響（表 5)

一定灌流量 $(1 \mathrm{ml} / \mathrm{min} / 100 \mathrm{gBW})$ 下での灌流圧は
Wistar : $114.4 \pm 9.6 \mathrm{mmHg}$, SHR : $95.0 \pm 9.6 \mathrm{mmHg}$ と両群に差がなく, この灌流圧はまた一定灌流圧の 150 $\mathrm{cmH}_{2} \mathrm{O}$ (=110.3mmHg) ともほぼ同じであり, 一方 $150 \mathrm{cmH}_{2} \mathrm{O}$ の一定灌流压下での灌流量はWistar : $1.14 \pm 0.20 \mathrm{ml} / \mathrm{min} / 100 \mathrm{gBW}$, SHR : $1.15 \pm 0.20 \mathrm{ml} /$ $\mathrm{min} / 100 \mathrm{gBW}$ と両群はほぼ一致し，これはまた一定灌 流量の $1 \mathrm{ml} / \mathrm{min} / 100 \mathrm{gBW}$ に近似している。これら灌 流圧と灌流量がほぼ一致した Wistar およびSHR 群 で一定灌流量群（非除神経群）と一定灌流圧群（除神 経群)の水排泄を比較すると Wistar, SHR 共に除神経 群に水排泄増加がみられ, 特に SHR では有意であっ $た(\mathrm{p}<0.01)$.

腎生理や腎における物質代謝を研究するために汎用 されている腎灌流法 ${ }^{10) ~ 12) ~}$ は高血圧の分野でもよく用 いられているが，この場合の腎灌流はいずれも灌流液 が循環する閉鎖式灌流で灌流液として血液あるいは血 液成分の含まれた溶液がよく使われている。その理由 
として一つの腎で灌流圧を変えて水, $\mathrm{Na}$ 排泄を検討 するため少なくも30分以上の腎灌流が安定状態で行わ れる必要から循環式で血液成分を有する灌流液が使わ れたものと思われる。血液以外の灌流液としては Krebs-Henseleit 溶液が良く用いられているが，この 溶液に組成がより近いラクテックと, 灌流液に必要と いわれているグルコースを含む $5 \%$ \%グルコース，また 浸透圧等の問題から牛血清アルブミンを加光た生食水 とラクテックで今回非循環方式を用いて, 水, $\mathrm{Na}$ 排泄 を検討してみた。 その結果, 生食水とラクテックで, 水, $\mathrm{Na}$ 排泄は同程度にみられ, 比較的安定した量が得 られバラッキも小さい事が証明された。ささらに組織所 見でも生食水はラクテックと同様に汪とんど腎に変化 が見られなかった．以上のことから我々は今回生食水 を用いて 5 分間のプライミング後 5 分間の非循環式腎 灌流法にて post-DOCA 高血圧腎と SHR 腎の水, $\mathrm{Na}$ 排泄を検討した。な拝定灌流圧下腎灌流で腎を体外 に取り出して行ったが, この際灌流液の温度を $20 \sim 40{ }^{\circ} \mathrm{C}$ で行い水, $\mathrm{Na}$ 排泄に温度による差がなかっ たことを予備実験で確認した。

Friedman $ら^{13)}$ は post-DOCA 正常血圧腎も postDOCA 高血圧腎とほぼ同程度の腎硬化変性をみ, BUN, CIn も両群間に差がみられず高血圧への腎の関 与をむしろ否定している。 しかし今回の検討でも前 回5) と同様コントロールの Wistarに比して血清クレ アチニンでは各群間で差がなかったが BUNでは post-DOCA 正常血圧ラットで軽度上昇し, postDOCA 高血圧症ラットで明らかな上昇をみ，後者によ り強い排泄障害の存在が考兄られた。 Post-DOCA 正 常血圧ラットでは whole bodyに括ける CIn, CPAH 共 にコントロールの Wistarよりも低下して招り細動脈 や糸球体の硬化変性の存在が示唆されたが, 腎灌流に おけるCInは Wistar と差がなく，腎の排泄障害の程 度は比較的軽度と思われる。そのため血圧は上昇せず 正常血圧範囲内で水, $\mathrm{Na}$ 排泄は正常に保たれている といえよう. Whole bodyに打け CInでは postDOCA 高血圧症ラットでコントロールの Wistar と有 意差なく，正常に維持されているが，これは高血圧の 状態にあるためであり, 灌流圧が $100 \mathrm{mmHg}$ 前後と低 くなるとCInは明らかに低下し，さらに腎灌流に捛け る水, $\mathrm{Na}$ 排泄能も同様に落ちていることから, postDOCA 高血圧症ラットは高血圧を維持することに よって水, $\mathrm{Na}$ 排泄を正常に保っていると解釈できる. また CPAHすなわち腎血流量が低下していることは腎
の細動脈壁の著しい肥厚変性が腎の排泄障害に影響し ていると考兄られる. Post-DOCA 高血圧腎での灌流 に拉ける水， $\mathrm{Na}$ 排泄についての報告はいままでにな いが，著者らは post-DOCA 高血圧症と post-salt hypertension はほぼ同じものと考えてきたが5)，両高 血圧腎とも腎硬化性変化を伴う水, $\mathrm{Na}$ 排泄障害で一 致する ${ }^{5) 8}$.

Arendshorst と Beierwaltes ${ }^{15}$ は 12 週 齢 SHR の腎 動脈分岐部近位の腹部大動脈縮窄を作成し, 正常血圧 の WKY の腎灌流圧までに下げた結果, WKY に比し て明らかな水， $\mathrm{Na}$ 排泄低下がみられたと報告してい る. Nagaoka $ら^{16)}$ も 9 週齢と15週齢の SHR に同様の 腹部大動脈縮窄を作成し水, $\mathrm{Na}$ 排泄低下を証明し, SHR の高血圧と腎の水, $\mathrm{Na}$ 排泄障害が関係あると述 べている.しかし Mullins と Banks ${ }^{17)}$ は高血圧前期 ( $6 \sim 7$ 週齢), 高血圧初期(12 13週歯), 高血圧持続 期（16〜17週齢）各々での SHR 腎機能を検討し， Na 負荷時の水, $\mathrm{Na}$ 排泄で 6 週齢では Wistar に比して低 下がみられたが, 正常血圧の WKY と同程度であり， 12週柃では Wistar, および WKY と差がみられず, 16 週㱓ではSHRの 2 コロニー中 1 コロニーのみ $\mathrm{Na}$ 排 泄増加をみたにすぎなかったので必ずしも SHR の高 血圧形成あるいは維持に腎の排泄障害が関与している と言い切れないとしている。一般に 5 週齢 SHR を高 血圧前期, $7 \sim 9$ 週龄を高血圧形成期, 13 週齢以後を 高血圧維持期とみることができ，今回の腎灌流による 検討では血圧が正常の 5 週齢ですでに同週齢 Wistar に比してCInは低下傾向を示し血圧が上昇し始める 7 週齢以降その低下は著明となった。水, $\mathrm{Na}$ 排泄は 7 ～9 週齢以降で 5 週齢に比して明らかな低下を示し 13 週龄では同週齢 Wistar, WKY に比して著しい低下と なった。以上の結果から 5 週龄ですでに腎の排泄障害 が存在し，それが血圧上昇高血圧形成ならびに持続の 一因となっている可能性が考えられた。

腎の水， $\mathrm{Na}$ 排泄に神経系が関与していることはよ く知られている.腎神経を遮断すると水, $\mathrm{Na}$ 排泄増加 がみられ，その機序として糸球体滤過の上昇 ${ }^{18)}$ 中尿細 管における再吸収の減少が考えられている ${ }^{199}$. 今回の Wistarでの除神経でも水排泄は増加傾向がみられ腎 神経の水, $\mathrm{Na}$ 排泄への関与を示唆した. SHR 腎の除 神経効果に関して多くの研究がなされているが

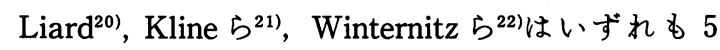
$\sim 8$ 週齢の高血圧前期および高血圧形成期の除神経で 高血圧形成が遅延したことから高血圧形成には腎の交 
感神経系が重要な働きをしていると考えている。

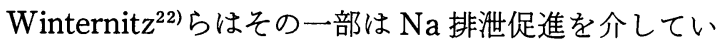
ると報告しており，高血圧が形成され持続期に入ると 除神経による血圧への影響はなくなり, 水, $\mathrm{Na}$ 排泄へ の効果もみられなかったと述べている。我々の実験で は明らかに除神経の13週齢 SHR 腎の水排泄が増加 し, Wistarに比してその増加が著明であった. Winternitz らの18週齢の SHR で除神経効果のみられなかっ たのは彼らが引用しているよらに, Folkow ら²3や Warshaw ${ }^{24)}$ の血管系構造変化が既にこの高血圧に おこっているのかもしれない。しかし Norman と Dzielak ${ }^{25}$ は 4 週齢から16週龄にかけて SHR 腎の除 神経によって血圧上昇をおさえた。これらと我々の結 果とを考兄合わせると，高血圧持続期に扮いても腎神 経系が高血圧維持に関係している可能性を否定できな い.

\section{結 語}

Post-DOCA 高血圧腎およびSHR 腎におけるイヌ リンクリアランス CIn と水, $\mathrm{Na}$ 排泄能をみる目的で 両高血圧腎の in situ と ex vivo 状態下の生食水によ る腎灌流を拈こない以下の成績を得た。

(1) Post-DOCA 高血圧腎の CIn おょび水, $\mathrm{Na}$ 排泄 の低下がみられた。

(2) SHR の週龄別の検討では 5 週齢の正常血圧時 にすでにCInは低下傾向がみられ，加齢とともに CIn, 水, $\mathrm{Na}$ 排泄能の低下が進行した。

（3）13週龄に打けるWistar正常血圧腎および SHR 腎の灌流にて除神経効果を検討し, 両腎ともに水 排泄の増加がみられ SHR 腎でその増加が著明であっ た.

\section{文 献}

1) Dahl, L.K., Heine, M. and Thompson, K.: Genetic influence of the kidneys on blood pressure. Evidence from chronic renal homografts in rats with opposite predispositions to hypertenson. Circ. Res., 40, 94-101, 1974.

2) Bianchi, G., Fox, V., DiFrancesco, G.F., Giovanetti, A.M. and Pagetti, D. : Blood pressure changes produced by kidney cross-transplantation between spontaneously hypertensive rats (SHR) and normotensive rats (NR). Clin. Sci. Molec. Med., 47, 435-448, 1974.

3) Thompson, J.M.A. and Dickinson, C.J.: The relation between the excretion of sodium and water and the perfusion pressure in the isolated, blood-perfused, rabbit kidney, with special ref- erence to changes occurring in clip-hypertension. Clin. Sci. Molec. Med., 50, 223-236, 1976.

4) Girardin, E., Caverzasio, J., Iwai, J., Bonjour, J. P., Muller, A.F. and Granschamp, A.: Pressure natriuresis in isolated kidneys from hypertension-prone and hypertension resistant rats (Dahl rats). Kidney Int., 18, 10-19, 1980.

5）村山猛男：ラットの post-DCA 高血圧発生におけ る腎の役割。日泌尿会誌，71，687-703，1980.

6) Kawabe, K., Watanabe, T.X., Shiono, K. and Sokabe, H.: Influence of blood pressure of renal isografts between spontaneously hypertensive and normotesnive rats, utilizing the $F_{1}$ hybrids. Jpn. Heart J., 19, 886-894, 1978.

7) Guyton, A.C., Coleman, T.G., Cowley, A.W., Scheel, K.W., Manning, R.D. and Norman, R. A.: Arterial pressure regulation: Overriding dominance of the kidneys in long term regulation and in hypertension. Am. J. Med., 52, 584-594, 1972.

8) Tobian, L., Johnson, M.A., Lange, J. and Magraw, S.: Effect of varying perfusion pressures on the output of sodium and renin and the vascular resistance in kidneys of rats with "post-salt" hypertension and Kyoto spontaneous hypertension. Circ. Res., 36(Suppl. 1), I162-I-170, 1975.

9) Tobian, L., Lange, J., Azar, S., Iwai, J., Koop, D., Coffee, K. and Johnson, M.A.: Reduction of natriuretic capacity and renin release in isolated, blood-perfused kidneys of Dahl hypertension-prone rats. Circ. Res., 43(Suppl. 1), I-92 -I-98, 1-98, 1978.

10) Nizet, A.: The isolated perfused kidney: Possibilities, Limitations and results. Kidney Int., 7, 1-11, 1975.

11) Ross, B.D.: The isolated perfused rat kidney. Clin. Sci. Molec. Med., 55, 513-521, 1978.

12) Thomas, M.: Physiological evaluation of the isolated perfused rat kidney. Am. J. Physiol., 238, F71-F78, 1980.

13) Friedman, S.M., Nakashima, M. and Friedman, C.L. : Further observations on "sustained" hypertension in the rat. Am. Heart J., 45, 864-872, 1953.

14）村山猛男：ラットの post-DCA hypertension に おける腎の役割一ラット腎移植による研究一, 日 泌尿会誌, 70, 88-95, 1979.

15) Arendshorst, W.J. and Beierwaltes, W.H.: Renal tubular reabsorption in spontaneously hypertensive rats. Am. J. Physiol., 237, F38-F47, 1979. 
16) Nagaoka, A., Kakihara, M., Suno, M. and Hamajo, K.: Renal hemodynamics and sodium excretion in stroke-prone spontaneously hypertensive rats. Am. J. Physiol., 241, F244-F249, 1981.

17) Mullins, M.M. and Banks, R.O.: Age-related changes in $\mathrm{Na}^{+}$excretion in saline loaded spontaneously hypertensive rats. Am. J. Physiol., 231, 1364-1370, 1976.

18) Kamm, D.E. and Levinsky, N.G.: The mechanism of denervation natriuresis. J. Clin. Invest., 44, 93-102, 1965.

19) Bello-Reuss, E., Colindres, R.E., PastorizaMunoz, E., Mueller, R.A. and Gottshalk, C.W. : Effect of acute unilateral renal denervation. J. Clin. Invest., 56, 208-217, ' 1975.

20) Liard, J.F.: Renal denervation delays blood pressure increase in the spontaneously hypertensive rat. Experientia, 33, 339-340, 1977.

21) Kline, R.L., Kelton, P.M. and Mercer, P.F.: Effect of renal denervation on the development of hypertension in spontaneously hypertensive rats. cnad. J. Physiol. Pharmacol., 56, 818-822, 1978.

22) Winternitz, S.R., Katholi, R.E. and Oparil, S.: Role of the renal sympathetic nerves in the development and maintenance of hypertension in the spontaneously hypertensive rat. J. Clin. Invest., 66, 971-978, 1980.

23) Folkow, B.G., Hallback, M.I.L., Lundgren, Y. and Weiss, L.: Structurally based increase of flow resistance in spontaneously hypertensive rats. Acta Physiol. Scand., 79, 373-378, 1970.

24) Warshaw, D.M., Mulvany, M.J. and Halpern, W. : Mechanical and morphological properties of arterial resistance vessels in young and old spontaneously hypertensive rats. Cir. Res., 45, 250-259, 1979.

25) Norman, R.A. Jr. and Dzielak, D.J.: Role of renal nerves in onset and maintenance of spontaneous hypertension. Am. J. Physiol., 243, H284-H288, 1982.

（1986年 4 月 26 日受付） 